\title{
Global Incorporation and Cultural Survival: The Surinamese Maroons at the Margins of the World-System
}

Aonghas St-Hilaire

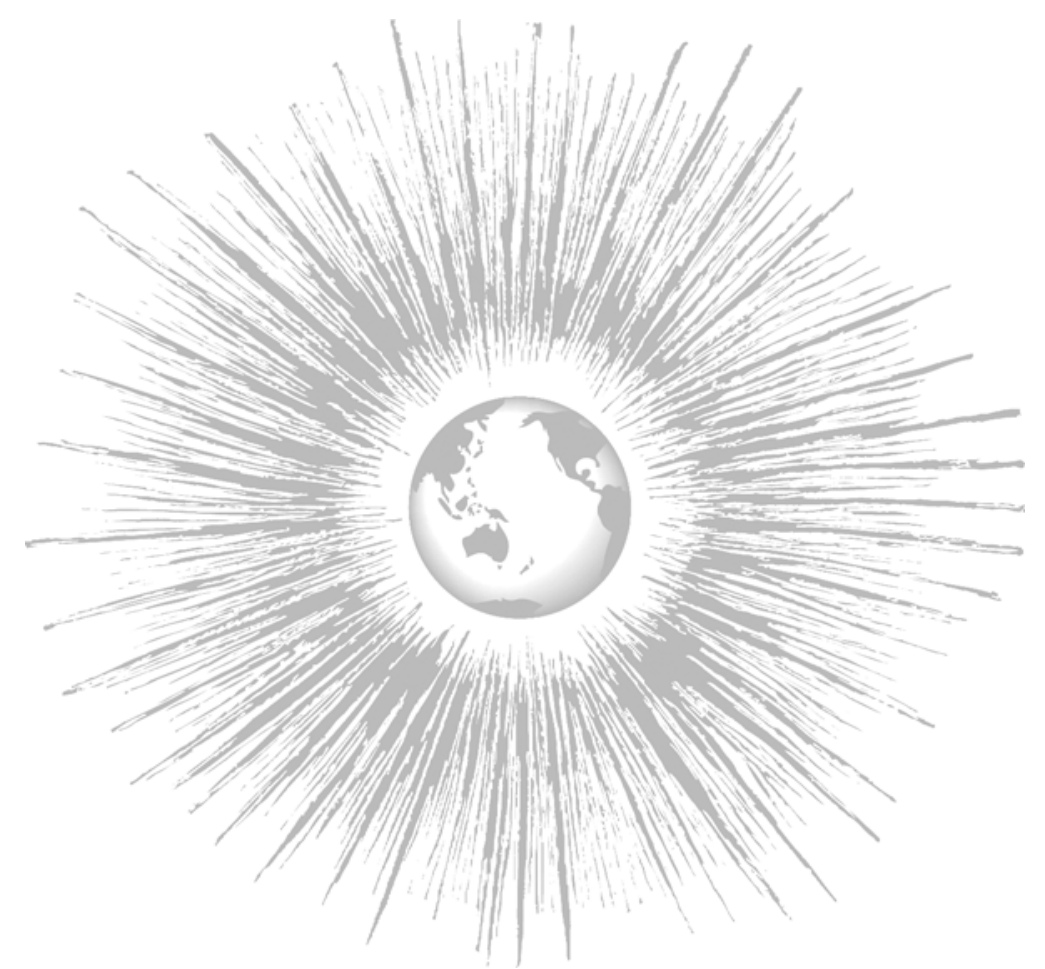

Abstract: The Maroons of Suriname enter the twenty-first century as the only surviving, culturally and politically autonomous Maroon communities in the Americas. The paper adopts a world-systems approach to explain the evolution of the Surinamese Maroon nations vis-à-vis the ever expanding Surinamese state and global political economy, with particular attention paid to the cultural survival of the Maroon nations. Prior to emancipation, limited colonial integration and mutual fear between the Maroons and Surinamese coastal society facilitated the development of the Maroon communities as relatively independent nations. Despite the best efforts of colonial authorities after emancipation, the weak economy and infrastructure of the Surinamese colony as well as continued mutual fear and distrust enabled the Maroons to guard their autonomy. However, after the Second World War, a period of global economic expansion, the rapid development of the Suriname as an integrated political, economic and cultural unit, and the depletion of and strain on natural resources in traditional Maroon territory dealt serious blows to Maroon autonomy. Maroon cultural survival depends on the ability of the Maroon nations to navigate the rapid changes currently affecting Maroon society, guarding political autonomy and cultivating the most treasured aspects of their cultural heritage, while participating, albeit peripherally, in modern global capitalism.

$\mathrm{O}$ f all the New World Maroons who struggled to forge independent communities in opposition to slavery and the harshness of plantation life, only the Maroons of south-central and southeastern Suriname continue on as culturally and politically distinct and viable entities through the present day. The Surinamese Maroons still live in relatively thriving independent communities in traditional tribal territory. Elsewhere in the Americas, Maroon societies were either destroyed or became integrated into the culture and society of the larger 'host' nation. Price (1976) asserts that the 
Maroons of Suriname, with over 300 years of independent history, represent the most highly developed independent societies and cultures in the history of Africans in the Americas. Vestiges of Maroon society hold on tenuously in Jamaica. Assimilation to the culture of the larger Jamaican nation has eroded the viability of the Jamaican Maroons as a distinct, independent community. In Suriname, however, six Maroon societies maintain linguistic, cultural and political norms that differ considerably from those of the urbanized and densely populated coastal region. The Saramacca, Matawai and Kwinti of south-central Suriname, and the Ndjuka, Paramacca and Aluku of the southeastern region remain distinct tribal entities whose autonomous political status finds support in eighteenth and nineteenth-century peace treaties and in historical relations between the coastal government centered in Paramaribo and the leaders of the different tribes.

The success of the Surinamese in maintaining autonomous life in the interior of Suriname belies a long history of attempts by colonial and later national governments to either destroy the independent Maroons or integrate them into larger Surinamese society. The autonomy of the Maroon tribal societies is currently threatened by the relative economic prosperity of the coast and the relative economic scarcity of life in tribal territory. While the Maroons successfully defended their autonomy during the fledgling years of tribal development and during the period prior to emancipation, efforts to integrate the Maroons into coastal society and the growth of economic opportunities on the coast, particularly since the end of the Second World War, have undermined the traditional autonomy of the various tribes. This paper examines the origins of the Surinamese Maroons, the development of Maroon society before and after emancipation, and the erosion of tribal independence after the Second World War, adopting a worldsystems perspective as the theoretical framework. Of particular interest is the continued cultural survival of the Maroon tribes as distinct societies given recent trends toward both global economic integration and the political, social and economic integration of Suriname as a nation. The worldsystems perspective explains the development and evolution of Surinamese Maroon society in relation to larger intersocietal networks. The genesis and the cultural survival of the Maroon tribes of Suriname are inextricably linked with dynamics operating within and through both larger Surinamese society and the global political economy.

\section{THE WORLD-SYSTEMS PERSPECTIVE}

Since European and later American colonial and capitalist economic expansion, every region of the world has become integrated into a single global political economy. World-systems theory calls this global entity the world-system (Wallerstein 1979; Shannon 1996). From the perspective of the minority, stateless cultural group, the important idea behind world-systems theory is that a nation or subnational region develops the way it does in part because of its position in the world-system (Wallerstein 1974). Further refinement of the concept is provided by Chase-Dunn and Hall (1991) who define world-systems as, intersocietal networks in which the interaction is an important condition of the reproduction of the internal structures of the composite units and importantly affects changes which occur in these local structures'. World-Systems theory looks at larger societal constellations to explain local societal change. The evolution of Surinamese Maroon society depends, therefore, on interaction with larger Surinamese society which, in turn, is influenced by participation in intersocietal networks at the global level.

The contemporary world-system is divided into three economic zones: core, semi-periphery and periphery (Shannon 1996). In the core, i.e. the industrialized countries of Western Europe, North America and Japan, production is capital intensive, using high-wage labor and the most modern technologies. In the periphery, where Suriname squarely lies, production relies on large quantities of relatively low-wage labor. Incorporation into the world-system is a continuum. Areas not yet included in the world-system are 'external arenas.' In the external arena, social life is typically marked by pre-capitalist forms of production and economic organization. In the process of incorporation into a larger world-system, external arenas frequently evolve into contact peripheries first, when outside influences are first felt within local society, then into marginal peripheries, as local social life grows increasingly dependent on larger networks of exchange, and finally into dependent peripheries, at which point traditional forms of economic and social life largely give way to those of the greater world-system.

Two trends characterize the evolution of the global political economy since the close of the fifteenth century: the broadening and deepening of capitalist production. Over the past 500 years, capitalist economic activities have steadily broadened, spreading into new geographic areas and integrat- 
ing more of the globe into the modern world-system. Also over the last five centuries, capitalist economic relationships have continually deepened, influencing ever greater aspects of life within societies already in the world-system. As a result of these trends, money has gained hegemony in regulating the exchange of goods and the provision of labor, production has become increasingly mechanized, social and economic relationships are increasingly regulated by formal, precise, legal arrangements, and communities have seen their traditional self-sufficiency wither away. Shannon (1996) argues that the contemporary world-system must expand in order to survive, particularly during periods of economic stagnation and falling rates of profit. During low points in economic cycles, such as periods of recession, capital seeks expansion, thereby providing the impetus for the continued integration of the world-system and for the incorporation of any remaining external arenas.

For cultural communities like the Surinamese Maroons, who enjoy a long history of relative autonomy, increased economic interdependence with coastal Surinamese society and the outside world may seriously undermine the long-term ability of these communities to survive as culturally and politically distinct entities within Suriname. Historically, the six Maroon tribes of Suriname have been thriving 'states within a state' (Price 1976). Although never completely independent of coastal Suriname, the Maroons of the interior have carefully guarded their political and cultural autonomy from Paramaribo. Prior to the 1940 s, the Maroons exhibited many societal features associated with the life in the external arena or with status as independent world-systems, albeit of small size and limited geographic extension. Wallerstein (1984) treats stateless societies that are not a part of the modern world-system as mini-systems, characterized by the production of basic subsistence goods within a single cultural community. The more discrete the economic, political and social boundaries of the Maroon tribal communities, the more correctly they may be regarded as mini-systems, independent of the larger Surinamese national and global political economies. Additionally, to the extent that the Maroon tribes maintain status as discrete minisystems, or entities operating in the external arena, the long-term cultural survival and viability of these unique communities are enhanced.

Chase-Dunn and Hall (1997) suggest that a mini-system tends toward discreteness if 'essential' interactions are carried out within a single cultural entity. If, however, interactions commonly cross cultures, the single cultural community is part of a larger world-system. Interactions occur through different networks of exchange. Bulk goods networks provide for the provision and exchange of food and raw materials. Marriage networks provide for marital linkages across component communities of a mini-system. Military and political networks encompass interactions through international or intercommunal relations, diplomacy and military conflict. Prestige goods networks and information networks constitute further determinants of system limits or fluidness. Procurement treks for food, raw materials and prestige goods delineate the boundaries of the mini-system. The exchange of brides and grooms similarly help delineate systemic boundaries. Conflict, in the form of disputes, raids, line wars, battles and retaliatory attacks also serve to fix systemic boundaries. Finally, the flow of information across composite units of exchange networks within a system aid in determining the systemic discreteness of a single cultural entity.

Integrated into the world-system as a peripheral region, Suriname has historically been a 'borderline society', evolving at the outer limits of European cultural influence (Lier 1977). The Maroons, at the margins of an already peripheral Suriname, have developed as distinct societies even further removed from the spheres of European cultural influence. Shared culture, however, is not a determinant of world-systems boundaries. Wallerstein (1979) defines the world-system as a multicultural network of exchange of necessities. Today there is only one global civilization or world-system. The world-system is based on connectedness, not uniformity. Communities whose people interact intensively, significantly and continuously belong to the same civilization, even when their cultures are dissimilar and their interactions are generally hostile (Wilkinson 1987). Nonetheless, there exist cultural characteristics that tend toward uniformity in the contemporary world-system. American pop culture, for example, disseminated by the U.S. film and music industries, now enjoys unrivaled influence throughout the world. In addition, the culture of industrial and technological modernity finds adherents among elite groups in all corners of the globe, encouraging the diffusion of a global consumer-oriented culture in the core, semi-periphery and periphery of the world-system.

Status groups, or social groupings whose solidarity is derived from a shared cultural identification constitute influential actors within the net- 
works of interaction in the world-system (Shannon 1996). Status groups are typically composed of members of the elites or highest classes of society. Status groups, through their control of capital, the media and national administrations, disproportionately influence the creation and maintenance of social norms. Sustained interaction between communities in the core and communities in the periphery affect cultural definitions of superiority and inferiority (Chase-Dunn and Hall 1993). As the interaction of social unequals intensifies, the cultural property of core status groups tends to gain in prestige and in numbers of adherents. Status groups in the periphery tend to model cultural behavior after status groups in the core, affecting the socio-cultural development of their respective national societies. In this process, the cultural property of human communities living outside the circles of power tends to be denigrated and is often associated with ignorance, barbarity and the primitive.

System boundaries are blurred or destroyed as interaction between two or more societies heightens. The nature of relations between two or more human communities coming in greater contact with each other influences the role of each community's respective culture in the emerging common world-system. This is particularly true for stateless cultural communities. In exploring the nature of intergroup relations and the emerging status of each group's respective culture, important questions to ask include; 1) Is systemic expansion achieved through conquest or some other means?, 2) Is local or long-distance trade increasing across cultural boundaries?, 3) Do more urbanized societies dominate or exploit hinterland societies? and, 4) How does urbanization spread? (Chase-Dunn and Hall 1997). Generally, when two or more societies of differential degrees of complexity, size and urbanization meet, an intersocietal hierarchy emerges in which members of less complex, small and rural communities come to constitute the lowest social rungs of the forming world-system. As the Surinamese Maroons increasingly integrate into larger Surinamese society, it is expected that their culture, suffering low status and social denigration at the national level, will undergo disproportionate challenges to change and pressures toward extinction vis-à-vis coastal Surinamese society. In the process of integration within the global political economy, stateless minority cultural groups lack the institutional support to recreate traditional cultural norms in the face of competition with nation-wide social institutions. National integration gen- erally translates into the assimilation of stateless minorities to the dominant national culture.

\section{THE CONTRASTING CASES OF JAMAICA AND BRAZIL}

Marronage was a common response of enslaved Africans throughout the Americas to the inhumanity of plantation life. In the early 1600s, under the Spanish, there already existed Maroon communities in the mountains of Jamaica. However, it was not until the British captured and colonized the island from 1652 onward that marronage grew to large-scale proportions. Plantation masters, with the backing of colonial authorities and their own private military forces, expended considerable resources to subdue the early Maroons. Nevertheless, by the 1680s and 1690, formidable bands of Maroons were well established in the Blue Mountains of eastern Jamaica and in the Cockpit Country of northwestern Jamaica. Efforts to destroy the Maroon communities bore little fruit. By the 1720s, the Maroons' numbers and organizational capacity had grown to such strength that the Jamaican plantocracy and colonial authorities lived in a state of continual anxiety and fear (Sherlock and Bennett 1998). Unable to conquer the Maroons and under increased threat of Maroon attack, colonial authorities were forced to sign peace treaties; first with Cudjoe, leader of the Cockpit Country Maroons, in 1739, and then with Quao, chief of the Blue Mountain Maroons, in 1740. Under the terms of the treaties, colonial authorities were to cease all military action against the Maroons and, for their part, the Maroons were to stop their attacks on the plantations and to refuse to harbor any new runaway slaves. More than 50 years of peace followed the treaties (Black 1983).

After the treaties of 1739 and 1740 , as a result of the cutting off of flows of new recruits, cultural divergence between the Maroons in the mountainous interior and the slaves of the coastal plantations advanced most significantly (Bilby 1994). However, with emancipation in 1838, the legal distinctions between the Maroons and the slaves disappeared, a factor working against the maintenance of a separate Maroon cultural identity. After 1838, contact between the Maroons and ex-slaves increased. Greater numbers of Maroons migrated to the coast and many ex-slaves took up settlement in or near the established Maroon communities (Black 1983). Over the next century, the Jamaican peasantry expanded into the areas bordering 
traditional Maroon territories and soon outnumbered the Maroons. As a result, cultural differences between the Maroons and other Jamaicans gradually eroded, leading some observers to the conclusion of eventual assimilation of Jamaican Maroons to mainstream Jamaican culture (Martin 1973; Bilby 1994). At present, Maroons and the rural Jamaicans living with or next to them speak the same language and follow virtually the same cultural practices. A distinct Maroon identity lingers on primarily due to the persistence of historical consciousness among many of the older Maroons (Martin 1973).

In Brazil, economically dependent on the plantation system and slave labor early in its history, the number of blacks reached 10,000 by 1580 (Parris 1976). Runaway slaves established the first Maroon settlements, or quilombos, in 1575 (Sherlock and Bennett 1998). Quilombos, persisting in various forms through the eighteenth century, came into existence on the geographic margins of plantation society throughout Brazil. Palmares, by far the largest and longest surviving of all Brazilian quilombos, controlled 27,000 square kilometers of territory, was composed of more than 1500 households, and had a population between 18,000 and 20,000 at its height (Russell-Wood 1982). In 1603, fearful of the presence of a thriving, politically independent ex-slave colony so close to the lucrative plantations, the governor general of Brazil sent an expedition to destroy Palmares and to bring its residents into subjugation. The attempt was a dismal failure (Parris 1976). It was not until 1697, after an intensive campaign initiated in 1691 by forces supported by the colonial government, that Palmares was finally destroyed. Other, smaller quilombos, however, were organized by runaway slaves during the century following the destruction of Palmares, providing refuge to those unable or unwilling to endure the rigors of enslavement on the plantations. Nonetheless, the quilombos of Brazil never gained formal recognition from colonial authorities. Extensive trade, via intermediary free settlers known as moradores, enabled the Brazilian Maroon communities to survive. By the nineteenth century, however, quilombos became extinct. In the 1800s, the presence of large numbers of free people of color, many of whom aided runaway slaves, obviated the need for quilombo-based living.

In contrast with the Surinamese Maroons, the Maroons of Brazil and, to a lesser extent, those of Jamaica, failed to maintain their status as distinct cultural and political entities. In Brazil, the quilombos vanished early in the nineteenth century. Although Africans have had an enormous impact on the development of the national culture of Brazil, there survive no autonomous or semi-autonomous Maroon-descended communities. The culture of resistence that the quilombos represented is extant in Brazil. Runaway Brazilian slaves never succeeded in pulling themselves from the periphery of the world-system and recreating social life in an external arena. From 1739 until 1838, however, the Jamaican Maroons maintained semi-autonomous communities geographically and socially removed from the coastal plantations, although with some limited individual contact with colonial society. Nevertheless, after 1838 the Jamaican Maroon communities gradually assimilated to the cultural norms of the larger Jamaican nation. Bilby (1994) affirms that the Surinamese Maroons have been able to maintain their isolation and independence much more so than the Jamaican Maroons. Few people in Suriname doubt the cultural distinctiveness of the Surinamese Maroons. In terms of cultural, political and social autonomy, contemporary Surinamese Maroons resemble the Jamaican Maroons of the late eighteenth and early nineteenth centuries and perhaps, to a lesser degree, the seventeenthcentury Maroons of Palmares.

\section{SURINAMESE MAROON CULTURE}

Today there are nearly 60,000 Maroons in Suriname. Of this number, approximately 25,000 belong to the Saramacca tribe, 25,000 belong to the Ndjuka tribe, 2,500 are Matawai, 2,500 are Aluku (who also live in French Guiana), over 2,000 are Paramacca, and a mere 500 form the Kwinti tribe (Hoogbergen 1990). Price (1975) asserts that each of the six Maroon tribes of Suriname uses a distinct language, follows a distinct diet, has its own type of dress, and displays unique patterns of marriage, residence and wagelabor migration to the coast. Cultural differences notwithstanding, when the granman, or paramount chiefs, of each tribe went on a trip to West Africa financed by the Dutch government, they marveled at the many cultural similarities between the various Surinamese Maroon tribes, on the one hand, and the African communities they visited, on the other (Groot 1974). Leerschool-Liong (1980) states that the culture of all six Maroon groups is similar. The six tribes are kept separate through tight individual political and social institutions. Hoogbergen (1990), however, maintains that each tribe is considerably different from the others in terms of language, religion and 
marriage patterns, but are similar to the others in terms of agricultural system and political structure. In spite of some common cultural ground, the different tribes have historically not maintained extensive social contact with each other, preferring instead exclusive intra-tribal social relations (Kahn 1931). In fact, there is evidence of inter-tribal hostility, particularly between the Ndjuka and the Paramacca (LeNoir 1973) and between the Ndjuka and the Aluku (Bilby 1991).

Each tribe, except the tiny Kwinti, has its own granman and formal government. The granman are generally regarded and treated as kings (Price 1976). Each tribe is broken down into clans called the lo. The lo is a matrilineage whose members can trace back to a common female ancestor. The paramount chief, or granman, of each tribe is chosen from within the different lo of the tribe (Goslinga 1990). Most Maroon villages are culturally homogeneous, typically being inhabited by members of the same lo. Kabiten, or headsmen, have lower rank than the granman and are the villages' most important political leaders. The tribal granman appoint the various village kabiten in consultation with village elders (Bilby 1991). The Ndjuka have 14 lo, the Saramacca 12, the Matawai 4, the Paramacca 4, the Aluku 7 and the Kwinti 2 (Hoogbergen 1990). The lo is further broken down into smaller matrilineages called the bee or bere. The bee or bere enjoys greater solidarity and a deeper sense of belonging than the lo (Jozefzoon 1959). Traditionally, Maroons get their primary social identity, their rights to land and associated resources and their many social obligations from clan membership, primarily through the bee or bere and secondarily through the lo. Membership in the bee or bere may vary from 50 to 200 (Thoden van Velzen 1990).

The function of the granman is often combined with that of high priest (Groot 1974). In fact, Maroon religion and political authority are inextricably linked with each other. Maroon traditional religion is African-derived, with positive and protective higher spirits and less reliable lower spirits that can take possession of human beings (Hoogbergen 1990). Grangado, or Supreme God, plays an important role in intertribal relations. Obia, similar to the Christian concept of the Holy Spirit, protects the Maroons in day-today life and was particulary important during the early days of escape and survival in the forest. Maroons cannot impose themselves on their natural environment at will, but must seek permission from and cooperation with the proper spirits (Leerschool-Liong 1980). In Maroon worship there exist strong feelings of a living bond with ancestors (Helman 1978). Jorka, or spirits of the deceased, are subordinate to Grangado and are reached in communication through rituals honoring them. There is today some fluidity between the religious practices of the urban Creoles and the Maroons of the interior. Many urban Creoles, although self-identified as Christian, also adhere to Winti, African- derived religious practices sharing features with various Maroon religious practices (Helman 1978; Spijkerboer 1986). Also, over the past 200 years, the efforts of Moravian and Roman Catholic missionaries have succeeded in converting many Matawai, Paramacca and Kwinti to Christianity. Nonetheless, religious practice in these tribes remains a syncretic blend of traditional Maroon religion and the rites of Christianity (Leerschool-Liong 1980). Among the other tribes, few Ndjuka, Aluku and Saramacca have converted to Christianity despite two centuries of missionary activity in tribal territory (Hoogbergen 1990; Thoden van Velzen and Wetering 1991).

In terms of language, the Saramacca and Matawai of the south-central region speak a common Creole, but sufficiently different from Sranan, the Creole lingua franca of coastal Suriname, to render the two mutually unintelligible. These two Maroon groups are historically related to each other (Green 1974). Their language, like many West African languages, makes use of tones to distinguish morphemes and, unlike Sranan, has a large proportion of Portuguese and African-derived lexical items (Voorhoeve 1971; Daeleman 1972). The Ndjuka, Paramacca and Aluku of the southeast also share a common language that differs considerably from Sranan (Hoogbergen 1990). Nonetheless, speakers of Ndjuka, Paramacca or Aluku and coastal speakers of Sranan can communicate with relative ease, as the languages are sufficiently related. Strong linguistic and cultural differences exist between the Maroon tribes of the southeast and the Maroon tribes of south-central Suriname (Voorhoeve 1971). The Kwinti language is different from all other Surinamese Creoles as far as the development of liquids is concerned (Smith and Huttar 1984). Price (1976) holds that the linguistic system of the Kwinti is not yet sufficiently described. Voorhoeve (1971), however, places the Kwinti in the same linguistic group as the Matawai and the Saramacca. The differences between the languages spoken by the Sarammacca and the Matawai and among those spoken by the Ndjuka, Paramacca and Aluku are only of dialectical nature (Plag 1993). Histori- 
cally, the Maroons made exclusive use of their languages within tribal territory, resorting to Sranan only for extra-tribal communication (Kahn 1931).

Maroon medicine relies on local herbs and plant oils in the treatment of dysentery, colds and the flu. Much of Maroon medicinal knowledge is borrowed from the Amerindians who must have shared the information with Maroons fleeing the plantations centuries ago (Helman 1978). In terms of agriculture and food, the Maroons generally produce only enough for themselves, not showing great interest in market trade with the coast (Mitrasing 1979). Manioc or cassava is the staple crop. There is also some local production of sugar-cane, cotton, peppers, okra, sweet potatoes, peas, beans, peanuts, plantains, yams, corn and rice. Fishing and hunting provide protein sources to supplement the mainly vegetarian diet (Groot 1977). Maroon women tend to live together and take care of the agricultural plots, while Maroon men are more ambulatory, fishing, hunting and migrating to the coast for work (Hoogbergen 1990). Women also collect fruit grown on lemon, banana, plantain, mango, nut palm, coconut and other fruit trees planted in the village. Among the Matawai, in addition to cultivating garden plots, women also do most of the fishing (Green 1974). Throughout the Maroon tribal territories, plots yield food around the year, but must be abandoned after two or three years due to soil depletion (Groot 1974).

All Maroon groups are matrilinear in structure. Marriage tends to be exogamous by lo, but within the same tribe. The practice of taking brides (or husbands) from different lo serves to reinforce intra-tribal cooperation and solidarity. Maroon men usually take more than one wife, provided the women live in different villages of the tribe and the men can provide for them (Groot 1974). Women tend to spend a much greater portion of their lives in Maroon tribal territory than men. It is increasingly common for men from all tribes to spend a large part of their lives outside Maroon territory, most often along the coast of Suriname or French Guiana, in search of temporary, semi-permanent or permanent work. The Ndjuka, living along a navigable river, have a long tradition of contact with coastal society in search of wage earnings and for the acquisition of additional provisions (Groot 1969). Saramacca men also have a long tradition of migration to the coast. The material culture of the tribal Saramacca includes both locally produced goods and goods acquired by men on the coast (Price 1975). Members of all Maroon tribes make regular excursions to Paramaribo or other urban centers of coastal Suriname and French Guiana for rice, flour, biscuits, salt, sugar, alcohol and canned goods. Within tribal territory, money has historically played a marginal role. Goods have traditionally been bartered and services have historically been paid in goods (Groot 1974). However, in recent years money has entered many tribal villages as a medium of exchange (LeNoir 1973), replacing kin-based modes of distribution with market-oriented modes and signaling a shift toward greater uniformity with coastal society and the larger world-system. Migratory wage labor thus at once sustains and corrodes Maroon distinctiveness.

\section{ORIGINS OF THE SURINAMESE MAROONS}

The six Maroon tribes make historical claims to a large part of Surinamese national territory (Mitrasing 1979). These claims are an historical continuation of the Maroons' original insertion into and subsequent partial withdrawal from the global political economy of the seventeenth, eighteenth and early nineteenth centuries in which enslaved Africans were forced to endure untold suffering and humiliation in order to produce sugar, molasses and rum for European consumption. Of Suriname's African slaves, approximately 13.5 per cent originated from the Windward Coast (Ivory Coast to Gambia), 18.5 per cent from the Gold Coast (Ghana), 37 per cent from the Slave Coast (Bay of Benin to the Bight of Biafra), and 31 per cent from Loango (Gabon and Congo) (Bakker et al. 1993). The English were the first Europeans to successfully establish a plantation economy in Suriname in 1651. The Dutch replaced the English as the colonial rulers of Suriname in 1667. For the first 100 years of Suriname's existence as a plantation economy, more than 90 per cent of all slaves were born in Africa. High mortality rates among the slaves due to the brutal living conditions of the plantations required a continual stream of freshly captured African slaves. Between 1668 and 1823, approximately 300,000 to 325,000 African slaves were brought to Suriname. However, at the end of this period there were only 50,000 people of African descent in Suriname (Price 1976).

Partly in response to the suffering of plantation life and partly in response to the accessibility of great tracts of forested land, slaves escaped and formed bands in the jungle near the plantations as early as 1651 (Kahn 1931). Hoogbergen (1990) states that the geography of Suriname is extremely suitable for offering shelter to Maroons. By 1667 there were 
already several hundred Africans living along Para Creek (LeNoir 1973). During the 1670s a civilian militia was created to destroy the emerging Maroon settlements, but attained limited success (Price 1983). In 1679 Governor Heinsius estimated the number of runaway Maroons in the forest at 700 to 800 . Throughout the 1680 s most slaves ran away singly or in groups of two or three (Price 1976). The first mass escape that would lead to the formation of the Matjau clan of the Saramacca tribe took place in 1690 (Bakker et al. 1993). These and the other early runaway slaves who would later become the Saramacca people were nearly all born in Africa, although from many different African nations (Price 1976). This may account for the high rate of Africanisms in Saramacca speech. Judging by similarities in language, the Matawai tribe was formed under similar circumstances. Most Saramacca and Matawai are descended from Maroons escaping before 1710 (Bakker et al. 1993). These African-born Maroons would often refuse to accept fleeing Surinamese-born slaves into their communities. Most African-born slaves cultivated small gardens in the forest near the plantations before escaping. Once having run away, the Maroons maintained kibrikondre, or hidden gardens, in which extra food was grown in case of attack by colonial authorities (Hoogbergen 1990).

By the beginning of the eighteenth century the Maroon population had rocketed to between 5000 and 6000 individuals (Price 1976; Groot 1977). New Maroon groups with identities distinct from the Saramacca and Matawai came into existence. Based on the similarities between the language spoken by the Ndjuka, Paramacca and Aluku and the coastal Creole language, these Maroon groups were likely formed at a later date and by a higher percentage of Surinamese-born slaves than the Saramacca and Matawai. Even during the early days, the Maroon groups had little communication with each other (Groot 1977). Marronage had become so widespread that Governor Coutier (1717-1721) implemented a policy requiring the execution of captured runaways in the hope of discouraging other slaves from fleeing the plantations (Thomson 1903). Nonetheless, the Maroons constituted little threat to the colony until around 1728 when the Maroons, whose numbers were rapidly growing, began intensive attacks on the plantations (Stedman 1796). Men, who made up 90 per cent of the original Maroons, raided the plantations for guns, gunpowder, machetes and women (Herskovitz and Herskovitz 1934). Within colonial society, the fear of
Maroon attacks became so great that many planters left the plantations for the safety of Paramaribo (Thomson 1903). In an attempt to neutralize the threat of the Maroons and stem the flow of fleeing slaves, colonial authorities enlisted 500 volunteers to patrol the plantations and to subjugate the raiding Maroons (Stedman 1796). Despite the efforts of colonial authorities, the Maroon raids on and the flight of slaves from the plantations continued.

\section{THE PEACE TREATIES: SOVEREIGNTY WON}

During the first century of their existence, the Maroons had not only successfully defended their hard-fought liberty, but had also threatened to shut down the local plantation economy. From the very beginning, the Surinamese Maroons refused to participate in the emerging world-system on English and later Dutch terms. Because of their reliance on plantation raids for weaponry and due to military conflict with colonial authorities, the Maroons are clearly a part of the global political economy of the seventeenth and eighteenth centuries. However, the Surinamese Maroons, more than any other African-American population, negotiated with remarkable strength their participation in the emerging world order. War expeditions against the Maroons were expensive and difficult and rarely succeeded in capturing more than a handful of runaway slaves (Groot 1977). The strength of the Maroons grew to the point that, through their frequent attacks on the plantations, they often led the colony to the brink of disaster and heightened the fear and insecurity of the colonists (Lier 1977). Faced with very bleak prospects of subduing the Maroons, Dutch colonial officials deemed it in the best interest of the colony to make peace with the different Maroon groups, thereby recognizing their right to exist as independent societies.

In the earliest days of the colony, runaway African and Amerindian slaves attacked the plantations. In 1683 peace was made with the Amerindians, releasing them from forced, unpaid servitude. In 1684 a peace treaty was signed with the earliest Maroons (Mitrasing 1979). However, slaves continued to run away from the plantations. During the eighteenth century, after more than 50 years of arduous and exhausting expeditions, colonial authorities decided to make peace with the three main Maroon groups and thereby cut their losses. Maroon distrust of colonial society complicated the peace- 
making process (Groot 1977). Nonetheless, peace treaties were successfully brought to term with the Ndjuka in 1760, the Saramacca in 1762 and the Matawai in 1767. The peace treaties stipulated that the established Maroons would turn over any subsequent runaway slaves. However, in practice the Maroons did not always do this (Hoogbergen 1990). The colonial government encouraged the Maroons' voluntary isolation in upriver, inland communities to protect the colony from future attacks. A pass system was implemented to limit the numbers of Maroons leaving tribal territory in the interior for the coast. This policy maintained its force until 1845. The Dutch stationed a posthouder, a diplomatic representative of the colony, in each of the Maroon tribal territories to facilitate relations between the colonial government and the Maroons (Groot 1977).

The peace treaties of the 1760s, however, did not stem the flow of runaway slaves to interior Suriname, despite the fact that established Maroon communities frequently did not welcome them and that recapture often meant death by execution. Runaway slaves founded three new Maroon tribes in the late eighteenth century with little or no help from the already organized Ndjuka, Saramacca and Matawai. The newly formed Aluku, Paramacca and Kwinti groups became havens for runaway slaves. The Aluku were a particularly fierce military force with which coastal society had to contend. Military hostilities between the Aluku and the Dutch lasted from 1769 to 1793 (Groot 1977). Most of the Aluku were either killed or driven into French Guiana. In 1791 a treaty placed the surviving Surinamese Aluku under the supervision of the Ndjuka (Chin and Buddingh 1987). The destruction and pacification of the Aluku marked the end of the Maroons as a disruptive element in coastal society (Goslinga 1990). The Paramacca and Kwinti were placed in protectorate relationships with the preexisting Maroon tribes, establishing a loose framework of indirect rule (Price 1976). For the Aluku, it was not until 1860, some 80 years after they had moved to French Guiana, that the Dutch recognized them as a free people (Bilby 1991).

Eighteenth-century treaties notwithstanding, the Dutch authorities, fearful of renewed Maroon attacks and the continued flight of runaway slaves, felt the need to renew existing treaties in 1835, 1837 and 1838, fixing the limits between the Maroon tribal territories and coastal society and reinforcing stipulations concerning runaway slaves (Groot 1977). There was a constant flow of runaways until around 1830. Between 1712 and 1830, Maroons represented approximately ten per cent of the total slave population of Suriname (Groot 1969). Maroon interpretation of history results in the belief of the Maroon tribes as sovereign nations. Maroons believe that colonial authorities had been unable to subdue them and had to offer peace for this reason (Groot 1977). The Saramacca, with a long history of struggle for independence, are particularly protective of their autonomous status. They fought for close to 100 years for the right to live freely before the Dutch finally made peace with them in 1762, a full centruy before the emancipation of coastal slaves (Price 1995). During the years before emancipation, the Maroons tended to hold to a belief in their moral and military superiority over the Dutch and coastal slaves, leading a relatively isolated existence in the interior of Suriname. Maroon tribal societies developed as states within a state until well into the nineteenth century (Price 1975). Nonetheless, the Maroons did maintain limited contact with coastal society for the procurement of particular goods deemed essential to Maroon life but not found or produced in Maroon territory.

\section{EMANCIPATIONः MAINTENANCE OF SOVEREIGNTY}

The Dutch abolished slavery in 1863. Emancipation brought new challenges to the Maroon tribes' historic status as sovereign nations. First and foremost among these challenges were ideas of change emanating from Europe. During the Industrial Revolution, the colonial powers of northwest Europe underwent great societal changes. Business and governmental leaders of the industrializing European polities intensified efforts to integrate all elements of their national populations into single, unified and smoothly running national economies. In addition, the French Revolution provided the ideological framework from which to push for the cultural and linguistic homogenization of ethnically and regionally diverse national populations (Oommen 1997). This concept of national development was exported to the colonies. In Suriname, authorities made Dutch-only education compulsory throughout the colony in 1876 , reversing centuries of colonial policy discouraging assimilation to Dutch. The Dutch hoped to transform Suriname into an overseas Dutch-speaking province of the Netherlands. Communal, familial and individual attachments to non-Dutch languages and cultures were regarded as obstacles to progress in the circles of Surinamese 
officialdom and high society. The language and culture of coastal Creoles, as the former slaves came to call themselves, suffered considerable social stigmatization and marginalization during this period. Assimilation to Dutch became the group ideal of urban Creoles and, later, of the East Indians and Javanese as well (Ramsoedh 1995). The autonomous Maroon societies, speaking various Creole languages and observing traditional cultural practices, were no longer viewed with fear, but were increasingly seen as undesirable holdovers from a primitive and uncivilized past.

In contrast with the rise of an influential industrial capitalist class in the Netherlands, Suriname's plantocracy of the seventeenth and eighteenth century remained a powerful influence in local society until around 1910. The premise of white superiority went virtually unchallenged until after 1945 (Goslinga 1979). After emancipation coastal Creoles were ingrained with racist thinking, holding to the notion of straight hair, light skin and speaking Dutch as good and desirable (Voorhoeve 1971). Accordingly, dark-skinned, Creole-speaking Maroons were held in a negative light by the urban Creoles (Kahn 1931). From about 1845, the Surinamese colonial government started taking steps to reverse nearly a century of policy encouraging the isolation of the Maroons. At this time, faced with an imminent labor shortage on the plantations, governmental officials consolidated relations with the Maroons, hoping to lure them from their woodland homes to settle in cultivated areas along the coast (Groot 1977). On the economic front, the period immediately following emancipation ushered in new work opportunities for Maroon men. Colonial officials came to see the vast interior of Suriname for its developmental potential, opening up the region to lumber interests and gold mining. Work in large-scale logging operations and river transport services became major sources of income for the Maroons through the Second World War (Price 1975). This work brought the Maroons into greater contact with the coastal population and exposed the Maroons to the prejudice against them in coastal society.

In response to the expanding Surinamese state, the Maroons experienced some pressure to adapt. However, the Maroons largely dictated the terms of their incorporation into the world-system, as they had done for nearly two centuries. Christianity provided an initial means of contact with the outside world (LeNoir 1973). Efforts by missionaries to Christianize the Maroons were designed to make the Maroons useful members of soci- ety' and facilitate their integration into Surinamese society (Groot 1977). However, the post-1845 efforts by Christian missionaries were of limited success. Of those Maroons who accepted Christianity, most integrated Christian practice with their traditional beliefs or kept the two separate (Goslinga 1990). Although mandatory Dutch-only education was implemented in 1876, its enforcement remained lax or non-existent in the rural districts and the interior of Suriname. By the early 1900s, however, colonial authorities attempted to integrate the Maroons into Surinamese society through formal education, encouraging missionaries to set up schools in tribal territory. The government also offered medical and agricultural aid. The Maroons kept their children out of the former and refused the latter. After failed governmental attempts toward integration, the Maroons were left alone until after the Second World War (Goslinga 1990).

The efforts by colonial administrators to integrate the Maroons into Surinamese society failed for a variety of reasons. A profound distrust based on the Maroons' historical memory of slavery and persecution by colonial authorities prevented acceptance of governmental overtures. The Maroons feared that the government aimed at taking away their independence. A conflict of perceptions contributed to the failure. The Maroons interpreted the peace treaties as setting out the guidelines for freedom and tribal independence, while colonial authorities interpreted these same treaties as merely a means to prevent Maroon attacks and limit the number of runaway slaves. The Maroons and colonial authorities failed to come to a mutual understanding, misjudging each other's motives and lacking an appreciation for each other's cultures and ways of life. Finally, the colonial government made decisions and took action without consulting the Maroons. The Maroons, on the other hand, resorted to the historical practice of defending their autonomy and discouraging any interference by government officials from the outset, thereby preempting any negotiations toward compromise (Kahn 1931; Groot 1977; Goslinga 1990). According to Kahn (1931), despite the best attempts by the Dutch to the contrary, the Maroons continued to live as they had during the previous century, albeit with additional goods acquired on the coast from wages earned in logging and river transport. Although the Dutch claimed sovereignty over the Maroon tribal territories, the Maroons paid no taxes, enjoyed virtually unlimited range of the interior, and led village and tribal life as they deemed fit. For all practical purposes, the sovereignty of the Dutch over the Maroons was nominal at best. 
WORLD WAR II AND ITS AFTERMATH: ACCELERATED CHANGE

The period following the Second World War witnessed great social transformations in both the world and Suriname. World War II was followed by an extended span of economic expansion, bringing the trappings of modernity to the four corners of the globe. The global political economy became increasingly integrated, with fewer and fewer regions of the world left untouched by the unprecedented world-wide change. Suriname, riding on the waves of global economic prosperity, experienced its own economic upturn, with a burst of local economic activity not seen since the early nineteenth century. With the local boom came road building, the construction of airfields and an hydroelectric dam as well as the mining of bauxite, now Suriname's principal earner of foreign reserves. Opportunities for unskilled labor abounded. Also during this period, the Maroons were experiencing substantial demographic growth. Their numbers had grown from a mere 8,000 in 1863 to 18,500 in 1923, and again to 22,000 in 1946 (Goslinga 1990). In response to both increased work opportunities within coastal society and increased environmental pressure and strain within the tribal homelands, larger numbers of Maroon men went to Paramaribo to earn a wage, making more frequent and lengthier trips to the coast than historically had ever been the case (Groot 1974). After 1945, the migration of men to the city in search of a wage became common cultural practice among all Maroon groups (Groot 1969).

After the Second World War, colonial authorities renewed efforts to expand and extend Dutch-language education (Karsten 1987). Dutchlanguage education was seen as the key to national unity, modernity and sustainable economic development. During the post-1945 period, nationwide assimilation to Dutch increased markedly, particularly in greater Paramaribo where more and more of the national population lived. In 1947 only 40 per cent of the national population lived in greater Paramaribo (Hellinga 1955). By the 1990s this figure had risen to over two-thirds. The Surinamese government relied on and supported Moravian and Roman Catholic missionaries to spread education to the Maroons. In 1963 there were 35 missionary-run schools in the tribal homelands. Groot (1974), however, asserts that most of what is taught is later lost for lack of use. A very large percentage of Maroons remain illiterate. In more recent years, the Summer Institute of Linguistics and local missionaries have stepped up efforts to teach literacy in the Maroons' native languages in addition to Dutch (Bakker et al. 1993; Dwarkasing 1994). The recent literacy programs have the catechization of the Maroons as their primary goal, thereby perpetuating a centuries-old missionary tradition of striving to bring Christianity to the Maroons.

Price (1975) states that prior to the 1960s, Western medicine, schools and Christianity made almost no inroads into Maroon tribal life and the authority of the tribal granman remained strong. Late in the 1950s, however, the national government established a series of police posts within the Maroon homelands. Between 1958 and 1961, the Surinamese government supported the construction of the Afobaka Dam on the Suriname River due south of Paramaribo, flooding a large portion of Maroon territory. Approximately one-half of traditional Saramacca territory was flooded by the dam (Price 1983). The dam was designed to produce hydroelectric energy to meet the needs of foreign bauxite mining interests in order to transform bauxite ore into aluminum for export. The hydro-electric project, designed and implemented without consultation with or the consent of the Maroons, displaced 5,000 to 6,000 Saramacca and Ndjuka, forcing the relocation of 21 Saramacca and five Ndjuka villages (Mitrasing 1979; Leerschool-Liong 1980). The dam exposed the Maroons, particularly those Saramacca living north of the newly created lake, to greater contact with the urban life of Paramaribo. North of the dam, the government built special planned villages for the thousands displaced by the lake (Price 1976).

In addition, the introduction of outboard motors reduced the traveling time between the Maroon homelands and Paramaribo. Airstrips were created throughout Maroon territory in the 1960s, allowing the Maroons and coastal residents to breach the great expanse of land separating most interior villages from the coast in less than an hour. The Maroons also experienced a demographic boom in the 1960s and 1970s. According to the Surinamese censuses of 1964 and 1971, the total population of Maroons living in Suriname climbed from 27,700 to 39,500, or 42 per cent (Dew 1978). The great population growth caused some shortages of basic necessities in the interior, encouraging further migration to the coast (Groot 1977). During the 1960s and 1970s, many Maroons moved to greater Paramaribo, primarily to the low-income margins of the city, as conditions in the interior deteriorated, transportation linking the interior and the coast improved and opportunities 
in the city expanded (Dew 1990). Since the 1960s, Maroons have become an important part of the labor force at the bauxite mining companies of Suralco and Billition and in greater Paramaribo. Urbanized Maroons have even become a minor force in national politics. However, tribal granman, to the extent of their ability, discourage Maroon participation in national politics, seeking to maintain group identity and solidarity through traditional tribal structures and relationships (Dew 1994).

\section{CONTEMPORARY TRIBAL SOCIETYः BREAKDOWN OR CULTURAL}

\section{ADAPTATION?}

Despite the changes in the global political economy, Suriname and the Maroon homelands during the 1960s and 1970s, Mitrasing (1979) observed that the Maroons, are still living in an African atmosphere and under archaic conditions, in spite many years of missionary activities, support and enlightenment'. Along a similar vein, Kobben (1968) noted that the Ndjuka maintain strong defense mechanisms against acculturation. External governmental interference has been insufficient to break Ndjuka resistance to change. Price (1976), however, asserts that the Maroons are facing intense pressures for sociocultural change, realizing that their traditional strategy of maintaining isolation holds little promise for the future. Counter and Evans (1981) point to the exhaustion of natural resources and the expansion of Western civilization to areas once isolated as threats to the cultural survival of the Maroons. The Maroons, in this view, are losing control over their lives and livelihood. There are a number of signs pointing to the influence of external governmental interference. Maroons now must pay a national income tax, although many do not earn enough income for this requirement to affect them, and the elderly and disabled receive small welfare payments (LeNoir 1973). The national government also provides paid employment for some Maroons within tribal territory. However, the Maroons are now liable for national military conscription. In addition, the national government, hoping to influence tribal politics, offer the granman of each tribe a salary, an outboard motor and a house in Paramaribo (Groot 1974). Green (1974) suggests that growing governmental largesse has increased the dependence of tribal Maroons on external actors.

The hope of integrating the Maroons into Surinamese society has been the primary motivating factor behind the largesse of the national government. The effects of external governmental interference are compounded by changing cultural patterns within the Maroon societies themselves. The migration of Maroon men to the coast for work has profoundly affected Maroon tribal society. Among the Matawai, for example, fertility is low because of the high absenteeism of males (Beet 1978). In the 1960s and early 1970s, there was a rapid depopulation of Matawai villages. In 1964 only 44 Matawai lived in Paramaribo. By 1972 this number had risen to over 1,000. More Matawai now live along the coast, principally in Paramaribo, than within Matawai tribal territory. Furthermore, Matawai men with semipermanent jobs in Paramaribo tend to bring their wives and children with them, reducing the likelihood of returning to the Matawai homeland. Even as early as the 1970s, Saramacca and Matawai men spent, on average, over two-thirds of their lives out of tribal territory, engaged in paid employment on the coast (Green 1974; Price 1975). Elst (1975) expresses concern that Kwinti society is on the verge of disintegration and suggests that elevating the tribal chief to the nationally recognized status of granman and exercising the right to exclude non-Kwinti people from Kwinti villages would boost the long-term survivability of the Kwinti as a distinct cultural community.

Among all Maroon tribes, as time progresses, Maroon men tend to stay away for longer periods. As a result, village and family ties become more tenuous. With a lack of men in the villages, problems arise with jungle clearance, house and boat building, and the fulfillment of marital, religious and administrative duties in the tribes (Groot 1977). In Maroon villages, particularly along the lower rivers, young men and boys are nearly all absent. The longer they spend on the coast, the more acculturated they become, losing respect for tribal elders and traditional Maroon ways. Many elders express the view that it is better for village life that many of these men remain on the coast (Counter and Evans 1981). Nonetheless, the depopulation of Maroon villages has become a serious problem (Price 1976). The Maroons are becoming an increasingly urban people. In 1964, approximately 2,400 or 8.7 per cent of all Maroons lived outside tribal territory (Dew 1978). At Surinamese national independence in 1975 tens of thousands of East Indians and Creoles left Paramaribo for the Netherlands, abandoning many small properties. Many Maroons moved into greater Paramaribo, buying up houses, shops and taxis at very low prices and establishing themselves permanently in the city (Thoden van Velzen 1990). In 1986 and 1987 the violence of a civil war between the national government and the Saramacca, 
Paramacca and Ndjuka in the interior further depopulated Maroon villages, sending thousands of refugees to Paramaribo and French Guiana for safety. By 1992 Maroons constituted 4.6 per cent of the total population of greater Paramaribo (Bruijne and Schalkwijk 1994). Hoogbergen (1990) estimates that of the approximately 50,000 Maroons in Suriname, 15,000, or 30 per cent, live in greater Paramaribo.

As the national Maroon population shifts to greater Paramaribo, the pressures toward acculturation intensify. Among these pressures are deeply rooted prejudice and discrimination against the Maroons in Paramaribo. Urban Creoles often regard the Maroons as 'half-naked primitives' (Dew 1994). Counter and Evans (1981) observed that a firmly entrenched color hierarchy divides the urban population of African descent into desirable lighter-skinned folk and undesirable darker-skinned folk. Urban Creoles, who tend toward mixed racial ancestries, often look down on the darkerskinned Maroons as backward and uncivilized. The urban population's negative attitudes toward the Maroons tends to marginalize them in urban society. The Maroons sit at the bottom of Suriname's social hierarchy (Mitrasing 1979). Even lower class urban Creoles, who have the greatest contact with urban Maroons, look down on them. Attitudes among welleducated urban Creoles toward the Maroons typically range from very paternalistic to deeply disdainful (Price 1995). Low social class, lack of family connections, ethnic prejudice and low levels of education have barred the Maroons access to many jobs in the public sector, Suriname's largest employer (Thoden van Velzen 1990). Faced with such intense societal disadvantage, the Maroons, generally with low or non-existent proficiency in Dutch due to limited exposure to education, speak Sranan in public to conceal their Maroon origins (Westmaas 1983). In a 1992 representative sample of households in greater Paramaribo, Bruijne and Schalkwijk (1994) found that of all urban Maroons, 57.9 per cent consider Sranan their primary home language, while 18.2 per cent have adopted Dutch for this function. Only 23.9 per cent maintain a Maroon language as the main language of the home.

Despite an unmistakable trend of assimilation to Sranan and Dutch among urbanized Maroons, there are signs of some resistance to complete acculturation. The traditional Maroon distrust of outsiders has historically served to reinforce group solidarity. Groot (1977) observed more than two decades ago that in the city, Maroons tend to keep to themselves, avoiding social contact with both people of other races and Maroons of other tribes. They prefer to maintain close contact with tribal kin. Urban Maroons maintain their mother tongue if they have frequent and extended contact with family and tribal members in the city or in the homelands (Westmaas 1983). As a counterweight to the prejudice Maroons face on the coast, the Maroons are very knowledgeable and proud of their history (Price 1975; Counter and Evans 1981). Tribal Maroons have historically harbored a sense of cultural superiority vis-à-vis coastal blacks, regarding the Creoles as disgracefully de-cultured. This attitude also applies within the different Maroon tribes. Upriver Paramacca, for example, consider themselves more culturally authentic or pure than their downriver tribal counterparts (LeNoir 1973). Whether or not tight intra-group solidarity and attitudes of cultural superiority will ensure the long-term survival of the Maroon tribes as culturally distinct and viable communities, however, depends largely on the future direction of the path of integration that the Maroons seem destined to follow.

\section{CONCLUSION}

Since their initial incorporation into the contemporary world-system in the seventeenth century, the Surinamese Maroons have had to struggle for their communal survival. The early global political economy was predicated on their subjugation or destruction. Nonetheless, despite the odds against them, the Maroons succeeded in creating autonomous societies at the margins of the world-system. Although never creating completely selfsufficient external arena societies, always depending on the coast for some of their economic needs, the Maroons did extricate themselves from the subservient, forced labor conditions on the peripheralized coast to establish themselves as politically sovereign and culturally independent nations with which the Dutch and Surinamese authorities had to reckon. The Maroons' evolution since initial incorporation has proceeded in tandem with changes both in Suriname and within the world-system. The trend toward greater integration among all component parts of the global political economy has proceeded at an unabated and increasingly rapid pace. Nonetheless, emancipation and the drive toward national integration in the late nineteenth and early twentieth centuries failed to break down tribal culture and politi- 
cal organization. It was not until the post-1945 period that the Maroons began to feel the growing pressure to adapt to a changing, tightly integrated economic world. Historically, lying in what might be characterized as the external arena of interior Suriname, the Maroons were able to guard their autonomy. The post-World War II period, however, witnessed unprecedented, heightened integration of the global political economy, integration that inevitably began to alter life in Maroon tribal territory. Capitalist economic relations both expanded to previously remote geographic regions and deepened within already integrated regions of the world. Today, the trajectory of continual global integration has resulted in a world-system in which no human communities, not even the historically isolated Surinamese Maroons, remain untouched and unaffected.

In terms of networks linking the tribes to the larger world-system, the Maroons have never been entirely isolated from coastal society. Traditionally, the Maroons provided for their subsistence food needs through the cultivation of gardens and through fishing and hunting. The Maroons supplemented their locally garnered food with products from the coast. However, the degree of reliance on the coast has increased drastically since the end of WWII, deeply affecting cultural reproduction in traditional Maroon society. The Maroons have also always been part of the larger world-system through military and political networks. The Maroons gained political recognition of their sovereignty only after many years of military struggle. The government of Suriname attempted to exert greater political control over the Maroons after emancipation, but failed in this endeavor until the 1960s and 1970s when governmental interference began to undermine traditional social structures among some Maroon groups. With the flight of workingage men to the coast in the post-1945 period, prestige goods networks linking the tribal Maroons and coastal society grew in strength. Manufactured goods, including transistor radios, became items of prestige among tribal Maroons. With the establishment of electric generators in Maroon territory by the national government in the 1960s, the Maroons' information networks expanded to include Paramaribo and the wider world. The past 30 years in the Maroon homelands have seen a deepening of the integration of Maroon society with Surinamese coastal society.

As Suriname has integrated as a national entity, local languages and cultures have lost ground to assimilation to Dutch, particularly in greater
Paramaribo where the vast majority of the national population now lives. Of Suriname's ethnic groups, the Maroons are least integrated into Suriname and the larger world-system. Of all ethnic groups, the Maroons have the lowest numbers of family members living abroad, the lowest rates of traveling abroad and the lowest mastery of the Dutch and English languages. Nonetheless, as the population of Maroons shifts increasingly from the interior to the coast, the pressures to assimilate to urban cultural norms and practices undermine the Maroon cultures and languages. The historic status groups of Suriname, the Dutch, and their successors, the Dutch-speaking Creoles, have successfully modeled the cultural formation of the nation. Historically, coastal society has looked down on the Maroons, denigrating their culture as backwards and uncivilized. As intergroup relations multiply through the integration of the Surinamese state and the disintegration of tribal society, the Maroons and their cultural property stand to lose much of their historic vitality. The growing influence of greater Paramaribo over the Surinamese hinterland is occurring both through the heightened interference of the national government in the tribal territories and through the large numbers of Maroons taking up residence in the city. While the six Maroon tribes of Suriname have historically enjoyed the status of states within a state, or independent nations of the external arena, they are gradually being demoted, through the steady erosion of their traditional autonomy, to minority ethnic groups within a multi-ethnic Suriname.

The future of the Surinamese Maroons as culturally distinct and viable societies depends on the continued ability of tribal leadership to successfully guard the political sovereignty of the tribes against the encroachment of the national government. This future also depends on the decisions of the Maroons, particularly urbanized Maroons, about the role of their tribal culture in every day life. Already, many urban Maroons, in the face of negative stereotypes and discrimination, have chosen to assimilate to urban Creole or Surinamese-Dutch culture, abandoning their unique cultural background as an antiquated relic. However, a minority of urbanized Maroons have opted to nurture ties with tribal kin in the city and in the homeland, adapting traditional Maroon culture to urban living. With an unprecedented number of Maroons living in Paramaribo, Maroons remaining in the tribal territories have greater contact with coastal culture. Tribal Maroons make more frequent trips to the coast, where family and village members offer 
homes in which to stay, and Maroons having spent extended time on the coast make visits or migrate back permanently to their villages of origin. The opportunities for cultural exchange abound. The danger for the cultural survival of the tribal Maroons lies in rejecting traditional Maroon culture as an obstacle to future prosperity. The optimal path of integration for Maroon cultural survival will combine the best of traditional Maroon ways of being and doing with advantageous cultural innovations emanating from outside the tribal homelands. At the world-systemic level, there is little indication of any reversal of the longstanding trends toward global economic integration. The isolation and autarky of previous generations no longer hold nor appeal to most Maroons. Maroon cultural survival hangs on the Maroons' willingness and ability to adapt to newly acquired, rapidly evolving, and multifaceted roles as tribal, national, and global citizens.

\section{REFERENCES}

Bakker, E. et al. (1993). Geschiedenis van Suriname: Van stam tot staat. Zutphen, Netherlands: Walberg Pers,

Beet, C. De (1978)."Male Absenteeism and Nutrition: Factors Affecting Fertility in Matawai Bush Negro Society," Nieuwe West-Indische Gids / New West Indian Guide 52(3/4):131-63.

Bilby, K. (1991)."The Emergence of an Ethnic Enclave: The Aluku," SWI Forum voor Wetenschap en Cultuur 8(2):48-55.

Bilby, K. (1994). "Maroon Culture as a Distinct Variant of Jamaican Culture," in E. Kofi Agorsah (ed.), Maroon Heritage: Archaeological, Ethnographic and Historical Perspectives. Kingston, Jamaica: Canoe Press, pp. 72-85.

Black, C. (1983). The History of Jamaica. London: Collins International.

Bruijne, A. and A. Schalkwijk (1994). Kondreman en P'tata: Nederland als representiekader voor Surinamers. Amsterdam: Instituut voor Sociale Geographie, Universiteit van Amsterdam.

Chase-Dunn, C. And T. Hall (1991). Core/Periphery Relations in Precapitalist Worlds. Boulder, CO: Westview Press.

Chase-Dunn, C. And T. Hall (1993).“Comparing World-Systems: Concepts and Working Hypotheses," Social Forces 71:851-886.

Chase-Dunn, C. And T. Hall (1997). Rise and Demise: Comparing World-Systems. Boulder, CO: Westview Press.

Chin, H. And H. Buddingh (1987). Suriname: Politics, Economics and Society. London: Frances: Printer.

Counter, S. And D. Evans (1981). I Sought My Brother. Cambridge, MA: Massachusetts Institute of Technology.

Daeleman, J. (1972). "Kongo Elements in Saramacca Tongo," Journal of African Languages $11(1): 1-44$.
Dew, E. (1978). The Difficult Flowering of Suriname. The Hague: Martinus Nijhoff.

Dew, E. (1990). "Suriname: Transcending Ethnic Politics the Hard Way." in G. BranaShute (ed.), Resistance and Rebellion in Suriname: Old and New. Williamsburg, VA: College of William and Mary, pp. 180-212.

Dew, E. (1994). The Trouble in Suriname, 1975-1993. Westport, CT: Praeger.

Dwarkasing, W. (1994). "Suriname: System of Education," in T. Husen and T. Postlethwaite (eds), The International Encyclopedia of Education, Volume 10. London: Pergamon, pp. 5846-54.

Elst, D. Van Der (1975). The Coppename Kwinti: Notes on an Afro-American Tribe in Suriname. Nieuwe West-Indische Gids / New West Indian Guide 50(1/3):7-17;10$22 ; 200-11$

Goslinga, C. (1979). A Short History of the Netherlands Antilles. The Hague, Netherlands: Martinus Nijhoff.

Goslinga, C. (1990). The Dutch in the Caribbean and in Surinam, 1791/5-1945. Assen, Netherlands: Van Gorcum.

Green, E. (1974). The Matawai Maroons: An Acculturating Afro-American Community. Doctoral dissertation, Catholic University of America. Ann Arbor, MI: University Microfilms.

Groot, S. De (1969). Djuka Societal and Social Change. Assen, Netherlands: Van Gorcum and Co., N.V.

Groot, S. De (1974). Surinaamse granmans in Afrika. Utrecht, Netherlands: Uitgeverij Het Spectrum.

Groot, S. De (1977). From Isolation towards Integration. The Hague: Martinus Nijhoff.

Groot, S. De (1977). Maroons of Surinam: Dependence and Independence. Annals of the New York Academy of Sciences 292:455-63.

Hellinga, W. (1955). Language Problems in Surinam: Dutch as the Language of the Schools. Amsterdam: North-Holland Publishing Company.

Helman, A. (1978). Facetten van de Surinaamse samenleving. Zutphen, Netherlands: Walburg Pers.

Herskovitz, M. and F. Herskovitz (1934). Rebel Destiny. New York: McGraw-Hill Book Company, Inc.

Hoogbergen, W. (1990). “The History of the Surinamese Maroons,” in G. Brana-Shute (ed.), Resistence and Rebellion in Suriname: Old and New. Williamsburg, VA: College of William and Mary, pp. 65- 102.

Jozefzoon, O. (1959). De Saramaccaanse wereld. Paramaribo, Suriname: Uitgave N.V. Varekamp and Co.

Kahn, M. (1931). Djuka: The Bush Negroes of Dutch Guiana. New York: Viking Press.

Karsten, S. (1987).“De koloniale onderwijspolitiek en haar gevolgen,” Oso 6(2):137-46.

Kobben, A. (1968). Continuity in Change: Cottica Djuka Society as a Changing System. Bijdragen tot de Taal-, Land-en Volkenkunde 124(1):147-64.

Leerschool-Liong, A. (1980)."Planned Research into the Criminological Consequences of the Mass Transportation of the Bush Negroes in Suriname," in R. BranaShute and G. Brana-Shute (eds), Crime and Punishment in the Caribbean. Gainesville, FL: University of Florida. 
Lenoir, J. (1973). The Paramacca Maroons: A Study in Religious Acculturation. Doctoral Dissertation, New School for Social Research. Ann Arbor, MI: University Microfilms.

Lier, R. Van (1977). Samenleving in een grensgebied. The Hague: Martinus Nijhoff.

Martin, L. (1973). Maroon Identity: Processes of Persistence in Moore Town. Doctoral Disseration, University of California, Riverside.

Mitrasing, F. (1979). Suriname: Land of Seven Peoples. Paramaribo, Suriname: Published by the author.

Oommen, T. (1997). Citizenship, Nationality and Ethnicity. Cambridge, United Kingdom: Polity Press.

Parris, S. (1976). Alliance and Competition: Four Case Studies of Maroon-European Relations. Baltimore: Department of Anthropology, The Johns Hopkins University.

Plag, I. (1993). Sentential Complementation in Sranan. Tübingen, Germany: Max Niemeyer Verlag.

Price, R. (1975). Saramaka Social Structure. Rio Piedras, Puerto Rico: Institute of Caribbean Studies, University of Puerto Rico.

Price, R. (1976). The Guiana Maroons. Baltimore, MD: The Johns Hopkins University Press.

Price, R. (1983). To Slay the Hydra: Dutch Colonial Perspectives on the Saramaka Wars. Ann Arbor, MI: Karoma Publishers.

Price, R. (1995). "Executing Ethnicity: The Killings in Suriname," Cultural Anthropology 10:437-71.

Ramsoedh, H. (1995). "De Nederlandse assimilatiepolitiek in Suriname tussen 1863 en 1945," in L. Gobardhan-Rambocus, M. Hassankhan and J. Egger (eds), De erfennis van de slavernij. Paramaribo, Suriname: Anton de Kom Universiteit, pp. 114-33.

Russell-Wood, A. (1982). The Black Man in Slavery and Freedom in Colonial Brazil. New York: St Martin's Press.

Shannon, T. (1996). An Introduction to the World-System Perspective. Boulder, CO: Westview Press.

Sherlock, P. and H. Bennett (1998). The Story of the Jamaican People. Princeton, NJ: Markus Wiener Publishers.

Smith, N. And G. Huttar (1984)."The Development of the Liquids in Kwinti," in P. Muysken and N. Smith (eds), Amsterdam Creole Studies. Amsterdam: Universiteit van Amsterdam, pp. 21-30.

Spijkerboer, A. (1986). “De reactie van de stadscreolen op het Christendom,” Oso $5(2): 129-35$.

Stedman, J. (1796). Narrative of a Five Years Expedition against the Revolted Negroes of Surinam. Baltimore, MD: The Johns Hopkins University Press.

Thoden Van Velzen, H. (1990)."The Maroon Insurgency: Anthropological Reflections on the Civil War in Suriname," in G. Brana-Shute (ed.), Resistence and Rebellion in Suriname: Old and New. Williamsburg, VA: College of William and Mary, pp. 159-88.
Global Incorporation and Cultural Survival

Thoden Van Velzen, H. And Wetering, W. Van (1991). The Great Father and the Danger. Leiden, Netherlands: KITLV Press.

Thomson, J. (1903). Overzicht der geschiedenis van Suriname. The Hague, Netherlands: Martinus Nijhoff.

Voorhoeve, J. (1971). “Church Creole and Pagan Cult Languages," in D. Hymes (ed.), Pidginization and Creolization of Languages. London: Cambridge University Press, pp. 305-15.

Wallerstein, I. (1974). The Modern World-System I: Capitalist Agriculture and the Origins of the European World Economy in the Sixteenth Century. New York: Academic Press.

Wallerstein, I. (1979). The Capitalist World Economy. New York: Cambridge University Press.

Wallerstein, I. (1984)."The Quality of Life in Different Social Systems: The Model and Reality." in I. Wallerstein (ed.), The Politics of the World Economy. New York: Cambridge University Press.

Westmaas, A. (1983). “De taalkeuze als meter van intimiteitsrelatie tussen veeltaligen," in E. Charry, G. Koefoed and P. Muysken (eds), De talen van Suriname. Muiderberg, Netherlands: Coutinho, pp. 169-99.

Wilkinson, D. (1987).“Central Civilization,” Comparative Civilizations Review, 17. 